We have now reached the end of the ninth year of the journal, and this will be my last editorial as Editor-inChief. So this is what it feels like to write my own obituary! I have a mix of feelings, including the sense of lightness that comes from being relieved of a burden and also some regret that I did not do more and better. I am delighted to be handing over to Agneta Yngve; Noel Solomons said to me at the First World Congress on Public Health Nutrition in Barcelona in September that he could not think of a more appropriate person to take over. Agneta, I hope you enjoy the job as much as I have.

What have we achieved? Well, we are now financially reasonably stable, we attract a lot of great papers, and in 2007 we become a monthly journal - 12 issues every year, to cope with the volume. Papers that have been accepted and proof-read are now available online as pre-publications, ensuring that they are in the public domain quickly. In 2007 the journal will move over to online submission and so the management structure will change; we will only have one point of submission.

It has been a source of great satisfaction to me that we have published papers reporting work undertaken in many different countries and based on collaborations between colleagues from many different institutions. Just taking one issue of the journal at random this year, papers covered work undertaken in 14 different countries; one study by Nana et al. ${ }^{1}$ was a collaboration between colleagues from universities in Burkina Faso and The Netherlands, and also with a colleague from Helen Keller International based in Niger. In the same issue was a global review of the impact of suboptimal breast-feeding among children in the developing world, written by colleagues from the World Health Organization and a Brazilian university ${ }^{2}$.

We are now completing a code of practice that I believe will be transparent and clear, in order to ensure that we behave properly and that our readers have confidence in the way we do our business. If we are to criticise others, we must make sure our own house is in order. We engage more in controversial issues and debate, and I believe we need more of this. While always protecting our academic credibility, we must be brave and engage in the real world. We must not be afraid to stand up and be counted when we see bad or fraudulent practice. When governments or industry propose or persist in bad policies and practices we should say so. We should encourage different voices to be heard, expressed independently and responsibly. I look forward to a much more dynamic and active correspondence section - I have been disappointed that some of what we have said has so far not provoked more reaction, although we have had some lively debates this year.

\section{Building capacity}

The discipline of public health nutrition is now well established. The Barcelona congress was a magnificent success; well done to Lluis Serra-Majem, Joy Ngo de la Cruz and their teams for their vision, energy and courage. At the congress a recurring theme was the need for capacity building and strengthening structures and systems. Many people said to me that it was great to be at a meeting that talked about making a difference, discussing ways to solve problems, not just to talk about their causes. We need to learn from our experiences and thus improve the effectiveness of our programmes and policies. We must learn from our failures, too, and be very clear what we are trying to do, and ensure that we have the right people in place to do the work.

In many countries, good well-trained people in our discipline are often sucked into other roles and responsibilities that take them away from service delivery and practitioner roles on the ground. Young people are right to want career enhancement, and we need systems that enable the right number and skill mix at every level of operation. We need workers and we need bosses too: people who create policies as well as those to turn policies into good practice.

My friends and colleagues ask me how I will cope with retirement. Well, I do actually have a day job! And also now I will be able more fully to commit to building public health nutrition into a profession that trains and supports and enables practitioners. Without a sound practitioner base we cannot build a sustainable profession. Public Health Nutrition as a journal will I am quite sure become increasingly crucial in this context, as a vehicle for communicating best practice, as a forum for sharing and learning, and as a voice speaking up for what is right.

\section{Acknowledgements}

I have so many people to thank for enabling Public Health Nutrition to be launched, to survive, to grow and now to prosper. Mike Gibney, President of The Nutrition 
Society when the idea of the journal was put forward, was prepared to back a new journal at a time when some said we were mad. We survived because of the dedication of our Editorial Board, and the support of the officers of The Nutrition Society. Special thanks to Lenore Arab and Marilyn Tseng, in our US office. And we have been sustained by our peer reviewers from all round the world.

I have worked with superb colleagues at CABI Publishing, and now at our new publisher Cambridge University Press. Sarah Lowe, our production manager at CABI, tolerated a great deal over the years especially in the way of late submissions and last-minute changes, and knew when to say no gracefully! Julie Hickman, the journal administrator, has put up with me since the beginning. Thank you all and thank you so many other friends and colleagues - you know who you are.

Barrie Margetts

Editor-in-Chief Public Health Nutrition, 1998-2006

\section{References}

1 Nana CP, Brouwer ID, Zagré NM, Kok FJ, Traore AS. Impact of promotion of mango and liver as sources of vitamin A for young children: a pilot study in Burkina Faso. Public Health Nutrition 2006; 9: 808-13.

2 Lauer JA, Betrán AP, Barros AJD, de Onis M. Deaths and years of life lost due to suboptimal breast-feeding among children in the developing world: a global ecological risk assessment. Public Health Nutrition 2006; 9: 673-85.

From January, authors are advised to check the Public Health Nutrition page or the homepage of The Nutrition Society website (http://www.nutritionsociety.org/index.asp?nsm $=3 \&$ page $=63$ or http://www.nutritionsociety.org) for details of online submission. 